\title{
Description of Male, Larva and Pupa of Stibasoma theotaenia (Wiedemann) (Diptera-Tabanidae)
}

\author{
S Coscarón/*/+, OA Mancebo*, CL Coscarón-Arias**
}

Facultad de Ciencias Naturales y Museo, 1900, La Plata, Argentina *Centro de Diagnóstico e Investigaciones Veterinarias, 3600 Formosa, Argentina **Facultad de Ciencias Agrarias, 8324 Cinco Saltos, Río Negro,

Argentina

Unknown male, larva and pupa of Stibasoma theotaenia from northern Argentina are described and illustrated. Larvae were collected from terrestrial Bromeliaceae of Aechnea sp. and maintained in the laboratory through development.

Key words: Stibasoma theotaenia - Tabanidae - description - male - immatures - Neotropical horse flies

Stibasoma Schiner is a Neotropical genus with 17 species distributed from Mexico to northern Argentina (Fairchild \& Burger 1994). The species are apparently bee mimics, with brownish coloration, stout body, and legs with abundant pilosity. The genus is characterized in the female as follow (Coscarón \& Papavero 1993): frons narrow, frontal callus as wide as frons; basal plate of antennal flagellum with elongate clubbed appendage, reaching or exceeding apex of plate; eyes with transverse stripes; wings with contrasting dark brownish pigmentation; fore tibia enlarged, remaining tibiae also inflated. Female genitalia unusual, genital furca with thick and divergent branches basally, sternum VIII narrow with median depression at base, cerci twice as wide as high.

Stibasoma theotaenia is known from Argentina, Uruguay, Paraguay and Brazil. The female was redescribed by Coscarón (1976), who also gave information about related species. The following is the first description of the male and immatures of this species and is based on larvae collected in 1997 in Formosa, Argentina. Immature stages of this genus are known only for four other species all of which breed in bromeliads (Goodwin \& Murdoch 1974). Information about adult habits indicates that these are arboreal species and few specimens have been collected biting man (Wilkerson 1979, Fairchild 1986).

Corresponding author. Fax: +54-221-425.7527. E-mail: museo@museo.fcnym.unlp.edu.ar Received 10 November 1998 Accepted 8 June 1999

\section{MATERIALS AND METHODS}

Larvae were collected in Formosa province near the city of Formosa $\left(26^{\circ} 16^{\prime} \mathrm{S}, 58^{\circ} 17^{\prime} \mathrm{W}\right)$, and near Ibarreta $\left(25^{\circ} 7^{\prime} \mathrm{S}, 59^{\circ} 11^{\prime} \mathrm{W}\right)$, about $200 \mathrm{~km}$ west of Formosa. Both areas are similar, but Ibarreta is more forested, both belong to the Chaco phytogeografic realm. The larvae were found in Aechnea sp., a very common terrestrial Bromeliaceae growing in shady areas below trees. Since larvae are encountered close to the bases of leaves collections were made to obtain the material by cutting the bromeliads near the ground and defoliating them leaf by leaf. Specimens were maintained individually in the laboratory in humid vials. Four flies (three females, one male) emerged from the pupae. The larvae did not accept some lepidoptera and coleoptera larvae as food. The larvae remained alive for 17 months.

Collections were made from April to November, and resulted in 75, mostly last instar larvae. Dead specimens were preserved in $80 \%$ alcohol in Museo La Plata and Centro de Diagnóstico e Investigaciones Veterinarias, Formosa collections; four specimens were mounted on microscope slides. In general, the immature terminology follows that given by Goodwin and Murdoch (1974).

\section{RESULTS}

Male: wing length $13 \mathrm{~mm}$. Overall color dark brown to blackish. Head black with upper large facets dark brown, small facets blackish, posterolaterally bordering large facets, gena gray pollinose, beard black, subcallus and clypeus subshiny dark brown. Antennae and palpi black with black hairs. Eyes wider than thorax, ocellar tubercle small and without ocelli. Proboscis short, shiny brown. Antennal basal plate with long tooth, apex reaching to end of basal plate. Palpi black with sparse grayish pollinosity and black hairs, subcylindrical, 
distally accuminate (Fig. 1). Thorax dark brown, scutum and pleural hairs black. Wings dark brown with discal and marginal cells paler (Fig. 2). Legs dark brown with black hairs, those of hind leg very long on both sides (Fig. 3). Abdomen brown, dark brown ventrally; terga I-IV mostly yellow pilose; terga III-IV with brownish hairs on basal half.

Genitalia: basistyle with basal border rounded, branches divergent, dististyle with a deep cleft, aedeagus as figured (Fig. 4). Cerci ovoid. Cerci and paraprocts with abundant hairs (Fig. 5).

Mature larvae: length relaxed 28-36 mm. Color dark grayish brown, slightly paler ventrally, sufficiently transparent to permit observation dorsally of the two main tracheal tubes and ventrally the digestive tract. Head dark brown. Specimens in alcohol become yellowish brown. General aspect as in Figs 6 and 7. Cephalic capsule yellowish brown, length 3.3-4.7 $\mathrm{mm}$. Cephalic appendages as in Fig. 8. Antennae with third article 0.33-0.41 times longer than second. Mandible length 0.45$0.58 \mathrm{~mm}$ with $11-13$ serrulations. Maxillae with two well-developed apical sensilae. Body integument covered with microtrichiae $0.03-0.04 \mathrm{~mm}$ in length, under low magnification appearing like velvety pubescence obscuring much reduced longitudinal integumental striations. Body trichomes with 1-3 branches emerging from base (Fig. 9). Thoracic trichomes submedial, $0.3-0.46 \mathrm{~mm}$ in length; segment I with $1+1$ dorsal, $1+1$ ventral and $1+1$ lateral; trichomes segments II, III with $3+3$ dorsal, $2+2$ ventral and $2+2$ laterally trichomes; abdominal trichomes $0.4-0.5 \mathrm{~mm}$ in length, morphologically similar to trichomes of the thoracic seg-

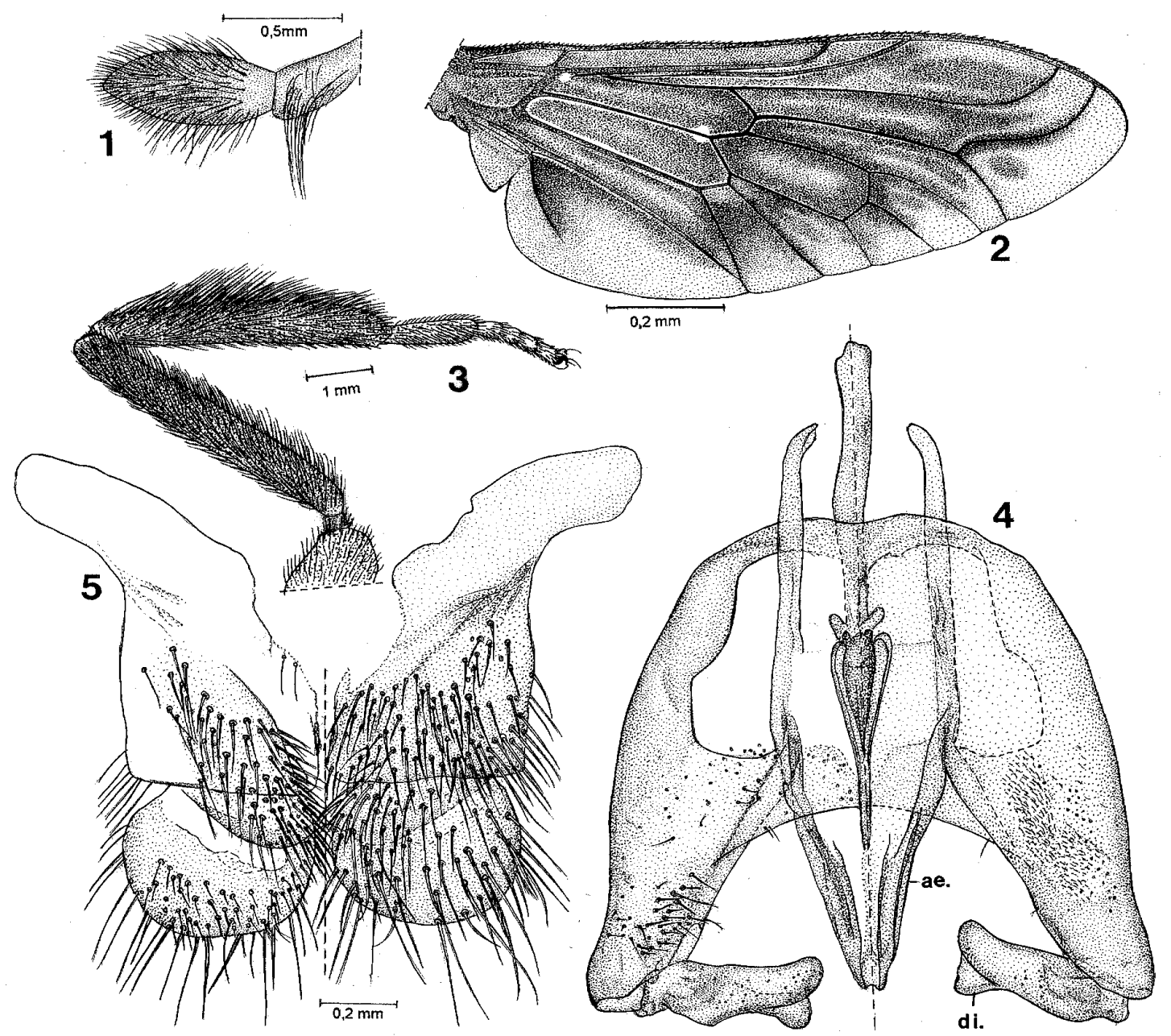

Stibasoma theotaenia, male. Fig. 1: palp. Fig. 2: wing. Fig. 3: hind leg. Fig. 4: basistyle, dististyle and aedeagus (ae: aedeagus; di: dististyle). Fig. 5: cerci and paraprocts (Figs 4 and 5 with same scale), (drawings based on the only specimen emerged, collected 7 $\mathrm{km}$ south from Formosa city). 

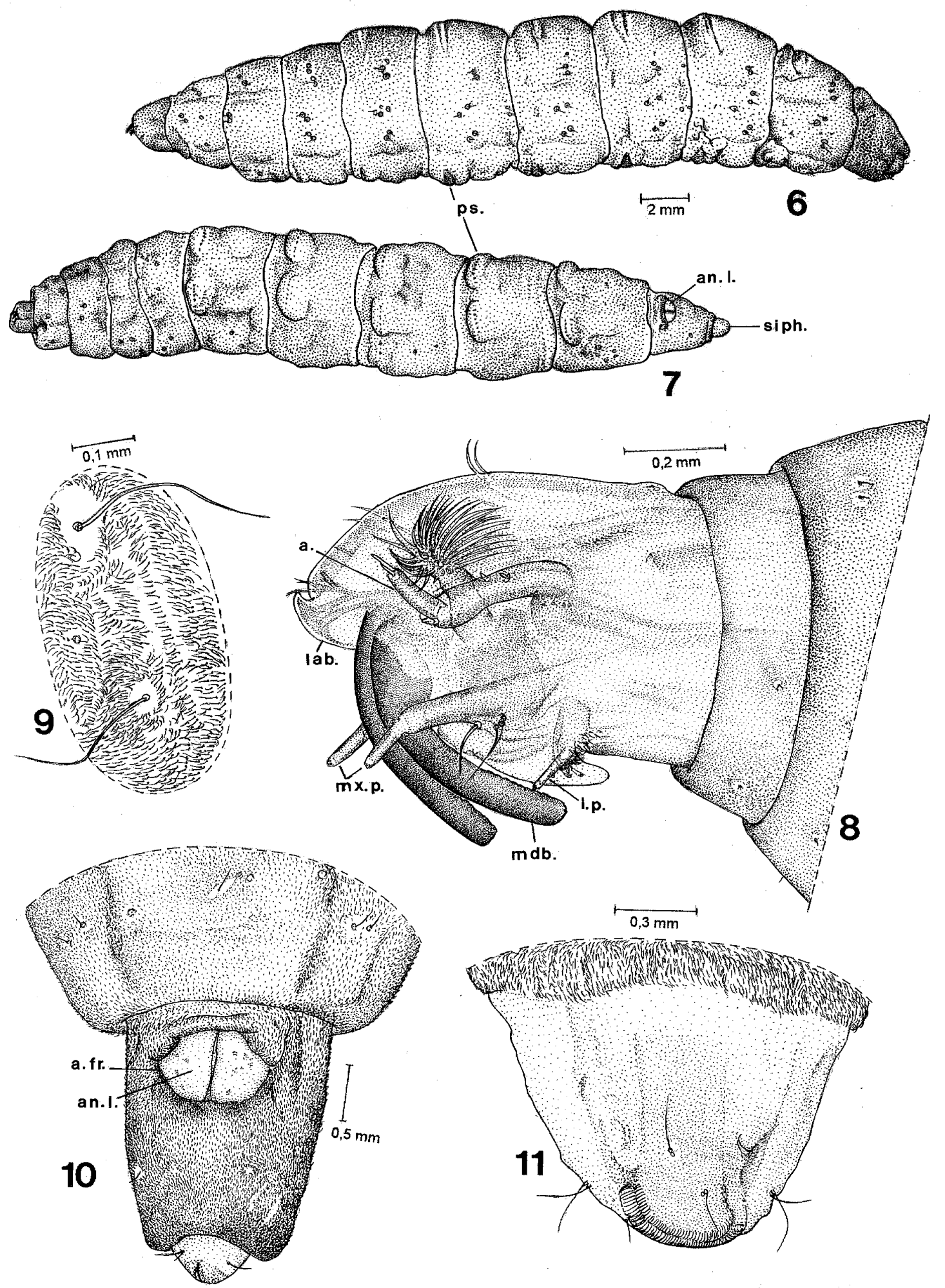

Stibasoma theotaenia, larva. Figs 6-7: general aspect in lateral and ventral view respectively (ps: pseudopodia; an.1.: anal lobes; siph.: siphon). Fig. 8: head partially projected (a: antenna; lab.: labrum; mx.p.: maxillary palp; mdb.: mandible; 1.p.: labial palp). Fig. 9: body trichomes and microtrichia. Fig. 10: anal segment and siphon in lateral view. Fig. 11: apex of siphon in lateral view (Figs 6 and 7 with same scale), (drawings was based on late stage larvae collected $7 \mathrm{~km}$ south from Formosa city). 

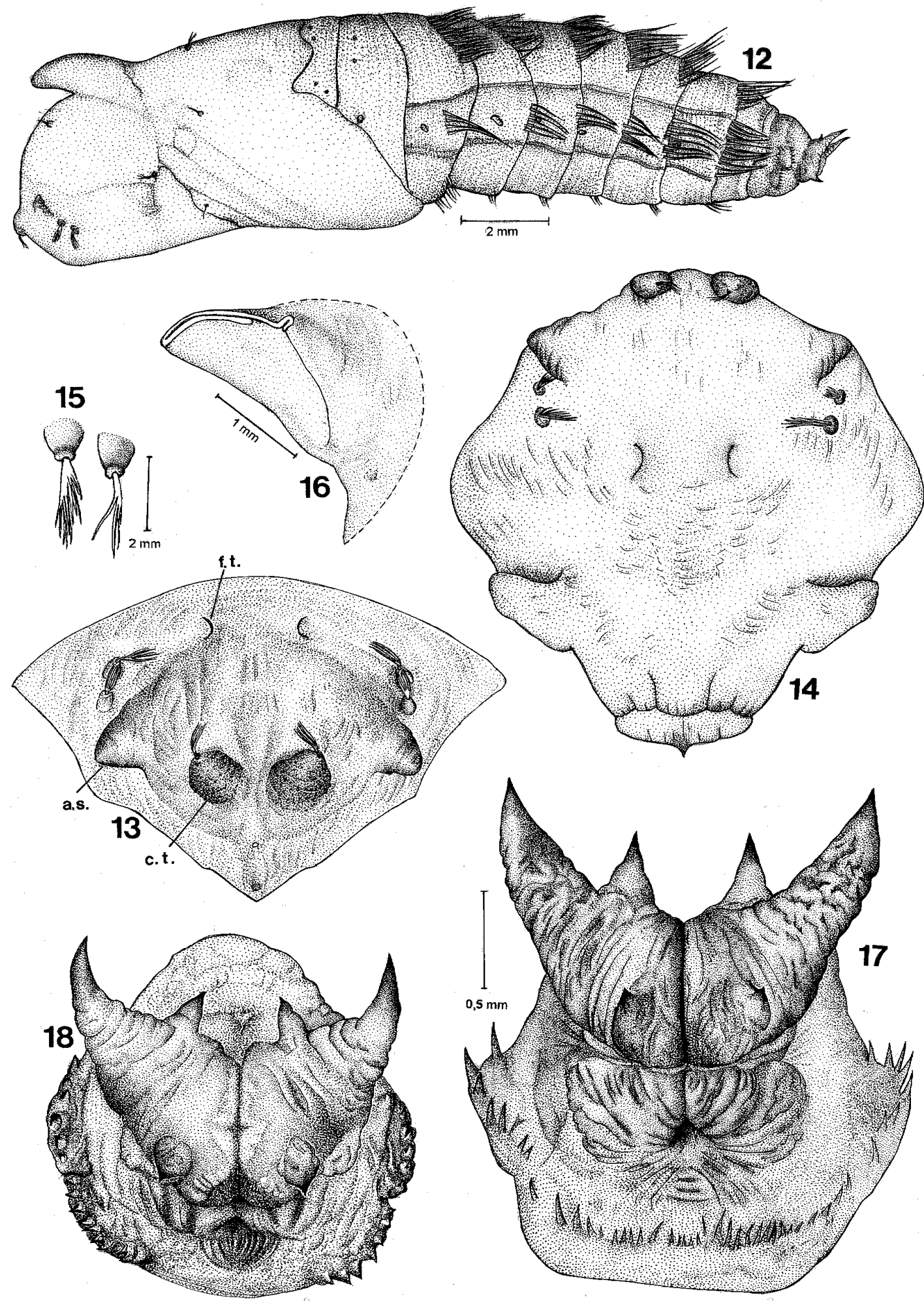

Stibasoma theotaenia, pupa. Fig. 12: general aspect. Figs 13-14: frontal plate in ventral and anterior view respectively (a.s.: antennal sheath; c.t.: callus tubercle; f.t.: frontal tubercles). Fig. 15: anterior orbital setae. Fig. 16: peritreme of thoracic spiracle. Figs 17-18: anal segment in posterior view of male and female respectively (Figs 13-14 and 16 with same scale, and Figs 17 and 18 also with same scale), (drawings was based on pupae emerged in the laboratory from larvae collected $7 \mathrm{~km}$ south from Formosa city). 
TABLE

Abdominal fringe; spine number and length $(\mathrm{n}=4)$

\begin{tabular}{lccccccc}
\hline Segment & II & III & IV & V & VI & VII & Length \\
\hline Tergite & $57-70$ & $60-70$ & $45-58$ & $39-43$ & $28-32$ & $19-26$ & $1.5-1.6 \mathrm{~mm}$ \\
Sternite & $20-37$ & $12-17$ & $10-18$ & $9-12$ & $14-19$ & $21-30$ & $0.5-0.7 \mathrm{~mm}$ \\
Pleura & $7-15$ & $7-13$ & $6-13$ & $9-12$ & $10-13$ & $14-28$ & $0.9-1.2 \mathrm{~mm}$ \\
\hline
\end{tabular}

ments II and III, sometimes with variable number, generally one on each. Abdominal segments I-VII with two pairs of transverse pseudopodia united mesally and covering anterior portion of tergita and sternita, simulating transverse ridges; ventral pseudopodia more prominent, sometimes like two flat subovoidal protrusions; no lateral pseudopodia but with two sinous invaginations simulating them. Pseudopod hooks single and small, 0.046$0.076 \mathrm{~mm}$ long. Anal segment 2.1-2.2 mm long, anal lobes fringed by abundant pubescence 0.046 $0.05 \mathrm{~mm}$ long (Fig. 10). Respiratory siphon 0.69 $0.76 \mathrm{~mm}$ long, with $1+1$ dorsal and ventral bifid trichomes (Fig. 11); trachea length 0.5-0.6 mm.

Pupa: exuvial color brown; maximum length 22$25 \mathrm{~mm}$. General aspect as Fig. 12. Antennal sheath 0.46-0.51 mm long, not reaching epicraneal suture in either sex (Fig. 13). Head capsule smooth with reticulate integument; antennal ridges moderately elevated, blunt distally without evident annulations. Callus tubercle relativelly well elevated, bearing stout and multibranched setae (Figs 13-14), front smooth reticulate; antero-orbital and postero-orbital setae well developed and subdivided into several short branches apically (Fig. 15). Thorax reticulate, wrinkled with $1+1$ anterior, $1+1$ posterior mesonotal and $1+1$ basealar setae. Spiracle prominences very elevated, $2.5-2.8 \mathrm{~mm}$ high, slightly accuminate distally; thoracic spiracle peritreme as in Fig. 16. Metanotum and abdominal tergita with transverse rugosities. Metanotum with $2+2$ notal and $2+2$ small lateral setae, mostly apparent only near tubercle insertion, also of reduced size. First abdominal tergum with 2+2 medial setae; pleural setae not apparent, as in following abdominal terga. Abdominal segments II-VII with fringe of long spines on terga, pleura and sterna; as in the Table. Dorso-lateral, lateral and ventral preanal combs composed respectively of 6-7, 6-8 and 21 spines in male and 5-7, 5$10,6+7$ in female (Figs 17, 18). Dorsal, lateral and ventral tubercles of aster 0.3-0.45, 0.9-1.0, 0.24-0.45 $\mathrm{mm}$ long respectively. Dorsal and lateral tubercles directed dorsally and second directed slightly posteriorly. Anal tubercle bilobed in male and single in female.
Material examined - Argentina: Formosa Province, April/October 1997 in terrestrial Bromeliaceae near the cities of Formosa and Ibarreta: 75 larvae, from wich 4 pupae developed, 3 female and 1 male emerged, plus 2 pupal exuviae retained.

Discussion: no differences were found between Formosa and Ibarreta larvae. The larvae are morphologically similar to the Stibasoma species described by Goodwin and Murdoch (1974).

Stibasoma mallophoroides (Walker) [= Stibasoma festivum (Wiedemann)] is also reported from the same area (Philip 1969). Based on illustrations and description of wing colloration, it is probable that this material corresponds to $S$. theotaenia. The type of $S$. mallophoroides is very similar to $S$. theotaenia, differing only by having a more hyaline discal wing cell.

\section{ACKNOWLEDGEMENTS}

To Nélida R Caligaris for illustrations and personnel from Centro de Diagnóstico e Investigaciones Veterinarias Formosa for help in the larvae collection work.

\section{REFERENCES}

Coscarón S 1976. Notas sobre Tabanidos Argentinos. XIV. Sobre los géneros Diachlorus Osten Sacken, Stibasoma Schiner, Stypommisa Enderlein, Cryptotylus Lutz y Chlorotabanus Lutz (Diptera). Rev Soc Entom Arg 35: 39-50.

Coscarón S, Papavero N 1993. An Illustrated Manual for the Identification of the Neotropical Genera and Subgenera of Tabanidae (Diptera), Museu Paraense Emilio Goeldi, Coleção Emilie Snethlage, Belém, $150 \mathrm{pp}$.

Fairchild GB 1986. The Tabanidae of Panama. Contrib Am Entom Inst 22: 1-139.

Fairchild GB, Burger JF 1994. A catalog of the Tabanidae (Diptera) of the Americas, South of the United States. Mem Amer Entom Inst 55: 1-249.

Goodwin JT, Murdoch WF 1974. A study of some Immature Neotropical tabanidae (Tabanidae). Ann Entom Soc Amer 67: 85-133.

Philip CB 1969. Descriptions of new Neotropical Tabanidae and new records for Argentina. Acta Zool Lilloana 22: 105-132.

Wilkerson R 1979. Tábanos (Diptera: Tabanidae) de los Departamentos Colombianos del Chocó, Valle y Cauca. Cespedesia 8: 89-433. 
624 Male, Larva and Pupa of S. theotaenia - Sixto Coscarón et al. 